\title{
Human Resource Management and SMEs Business Growth in Pakistan
}

\author{
Nadeem Bhatti ${ }^{1}$, Anwar Ali Shah G. Syed ${ }^{2}$, Syed Munir Shah ${ }^{3} \&$ Faiz. M. Shaikh ${ }^{4}$ \\ ${ }^{1}$ North American College, Toronto, Canada \\ ${ }^{2}$ Faculty of Commerce \& Business, University of Sindh, Jamshoro, Pakistan \\ ${ }^{3}$ Faculty of Commerce \& Business Administration, SALU, Khairpur, Pakistan \\ ${ }^{4}$ SZABAC, Dokri, Larkana, Sindh, Pakistan \\ Correspondence: Dr. Nadeem Bhatti, North American College, 730-Yonge Street, Suite No. 207, Toronto M4Y \\ 2B7, Ontario, Canada. E-mail: nadbhatti@yahoo.com
}

Received: December 4, 2011

Accepted: February 2, $2012 \quad$ Published: May 1, 2012

doi:10.5539/ass.v8n6p136

URL: http://dx.doi.org/10.5539/ass.v8n6p136

\begin{abstract}
This research investigates. Data were collected from 100 respondents from 30 organizations by using simple random technique. A structural questionnaire was developed to get reliability of the Data. Data were analyzed by using SPSS-18 version. It was revealed that SMEs are the major source of foreign exchange earnings, SMEs have a major contribution in Pakistan's GDP, A known feature of SME sector is its ability to create jobs, SMEs maintain the poverty alleviation activities through creating employment, SMEs assist in fostering a self-help and entrepreneurial culture, SMEs boost up an entrepreneurial strength which puts forward flexibility in the economy, SMEs are more capable in resource allocation as compared to large scale industries, SMEs in general consider employees as their most important resources, SMEs are pioneer in developing new products and services and finally SMEs are in general very quality minded in the products and services they provide.
\end{abstract}

Keywords: SMEs, employment, sector, Sindh

\section{Introduction}

SMEs on creation of employment, section three investigates the importance and significance of SMEs, section four addresses behavior of employer/manager in official and un-official matters with the employees, section five explores the appointment procedure in SMEs, section six discovers the contribution of SMEs to private sector employment section seven find out the contribution of SMEs to government sector employment, section eight highlights on the growth of SMEs in Sindh, section nine determines the performance/improvements of SMEs in textile industry of Pakistan during last five years, section ten assesses the role of textile industry of Pakistan in creation of job opportunities in the country, section eleven evaluates the fundamental role of textile sector in the exports of Pakistan, section twelve inspects the performance of textile sector in the development of the manufacturing sector in Pakistan and finally section thirteen observes the contribution of SMEs in employment of Pakistan.

\section{Literature Review}

SMEs have historically taken as a significant part in contributing to economic progress of many countries around the world (Kongolo, 2010). There is no growth when the advantages of economic improvements are utilized only by a small number of people, whereas the greater parts are being expelled (Todaro and Smith, 2003). The unconstructive effects of current economic turn down have seriously influenced the socio-economic conditions of many people universally. As a reply to these negative conditions, it is necessary that the small, medium and large entrepreneurs improve their employment formation capabilities (Barakat, 2001). It was also pointed out by the Advani (1997) that from the socio-economic development point of view, SMEs provide a variety of benefits. A well-supported and enhanced small business sector is likely to continue contributing to the economic development process in the same way as a large business (Abraham, 2003). One of the noteworthy distinctiveness of a prosperous and emergent economy is a booming and blooming small and medium enterprises (SMEs) sector (Feeney and Riding, 1997). 
Feeney and Riding (1997) further argued that small and medium enterprises play an important role in the development of a country. According to Fida (2008) SMEs contribute to economic development in various ways: by creating employment for rural and urban labor force, providing desirable sustainability, and innovation in the economy as a whole. In addition to that, large number of people relies on the small and medium enterprises directly or indirectly. Cook and Nixson (2000) also gave arguments in favor of SMEs according to him the growth of SMEs is seen as the way to accelerating the accomplishment of wider socio-economic objectives, including poverty mitigation. The growth and efficiency of small enterprises have also become famous (Mazumdar, 1997). Using the case of Northern Italy, Piore and Sabel (1984) have argued that small enterprises are more efficient because they have adopted a flexible specialization approach. In the same way, there has been growing interest in whether this model has or can be replicated in developing countries (Schmitz, 1989; Pederson, 1994; Schmitz and Musyck, 1994; Schmitz, 1995). Considerable attention has been paid in the last decade to the problem of poverty-reduction in developing countries. (World Bank, 1989, 1997). It is generally agreed that the development of micro and small-scale enterprises (MSEs) can be a key ingredient in poverty-reduction (Sen, 1980 and Green et al, 2002). On the other hand, evidence shows that small-scale enterprises contribute significantly to household incomes (Liedholm et al., 1994; McPherson, 1996; Kapoor et al., 1997; Perks, 2004; McDade \& Spring, 2005). It is also globally experienced that a well-organized SME sector is favorable to rapid industrial intensification (Hill, 2001, Llyod 2002).

\section{Data Collection Methodology}

Data were collected from 100 respondents from 30 organizations by using simple random technique. A structural questionnaire was developed to get reliability of the Data. Data were analyzed by using SPSS-18 version.

Proper management of a company's human resources is key to business survival in today's world. The organizational effectiveness of the firm (Perry, 1993; Huselid, 1995; Terpstra and Rozell, 1993) and its ability to create a sustainable competitive advantage (Prahalad, 1983; Pfeffer, 1994) can hinge on whether HRM practices are properly thought out and successfully implemented. The human potential in a company is generally much more difficult for competitors to duplicate than the plant, equipment or even products that a company produces (Flanagan and Despande, 1996). Consequently, the nature and well-being of a company's employees can become its main strength in carving out a profitable existence in the industry. HRM practices can be particularly important for small firms (Marlow and Patton, 1993). Research indicates that inadequate and inefficient management of employees in small firms has resulted in low productivity and high turnover rates (Mathis and Jackson, 1991) and is one of the leading causes of small firm failures (McEvoy, 1984).

\section{Human Resource Management and SMEs}

Research put forward that smaller entrepreneurial firms usually have key confronts with HRM for the reason that the small size of the firm often does not guarantee appoint professionals completely dedicated to HRM proceedings (Hornsby and Kuratko 2001; Hornsby and Kuratko 1990; Wager 1998; Bacon et al. 1996). SME sector is facing a lot of disputes in business administration, mostly capable and effectual use of funds to accomplish managerial objectives. Research shows apprehension for owner-managers' administrative performance and their impact on firm operations. A small number of studies in this sector draw concentration to conventional administration performance including HRM and anxiety for a solid framework to manage firm resources particularly human resource which is regard as a key resource. According to Brand and Bax (2002) many small firms meet serious human resource problems, at the same time as; human resources are taking a crucial part in rising and sustaining their competitive advantages. They have also concluded that the existing knowledge on HRM in small firms is extremely explanatory and fragmented.

Institutionalisms (e.g. Hall and Soskice, 2001; Whitley, 1999) argue that national factors such as economics, governance, financial and legal systems and trade unions, which together form the national business system, are the source of the main differences in RM between nations. We will shed some light on the national business system of Pakistan, with an objective to look how and/or what type of impact these can have for the development of HRM in SMEs. Moving ahead in this part first is SMEDA.

\section{Importance of $\mathbf{H R}$}

The human resource department is the group formally established by an organization to help manage the organization's people as effectively as possible for the good of the employees, the company, and society (Schuler and Jackson, 1987). Entrepreneurship is a process of value creation in which an individual or team brings together a unique package of resources to exploit an opportunity (Jones et al, 1995). In small firms, where resources are likely to be scarce, there may be a very small number of formal HR departments or professionals, increased difficulty in recruiting and retaining employees due to lack of financial resources, and an increased 
reluctance to engage in costly or restrictive practices (Cardon and Stevens, 2004). Most small businesses do not have formal HR departments; all firms have recruitment and HR policies, even if they are only implicit (Aldrich and Von Glinow, 1991).

Schuler and Jackson (1987) assuming critical role of HR department, explains the many roles of the human resource departments as "Effective firms in the highly competitive environments of today encourage their HR departments to play many roles. The more roles they play well, the more likely they will be to help improve the organization's productivity, enhance the quality of work life in the organization, comply with all the necessary laws and regulations related to managing human resources effectively, gain competitive advantage, and enhance workforce flexibility."

\section{HR Functions}

As firms grow, there is a need to administer the HR function. HRM department is considered responsible for executing all HR function in best interest of the firm. Human resource functions can be defined as the way all tasks and responsibilities regarding HRM are organized within organizations. HR-functions include all roles, tasks and responsibilities from the staffing process, to the training and development via the performance planning and appraisal to remuneration and other rewards to finally the termination of employment. The HR-function does not only involve managers in general or at HR departments, but also line management and even the employees themselves. Various organizational contextual factors determine the need for some specific HRM practices causing HR function (as principal task of HRM department) to play their role effectively. However, HR functions depend on some other factors, as Hendry and Pettigrew (1992) explain that "while changes in human resource practice can be conceived as a response to business strategy, the scope of the HRM function to respond effectively is therefore limited by its role and resource". It is the job of HRM manager and/or department within any organization to define their HR function through need analysis survey for helping business operations and gaining sustained competitive advantage. These may comprise of Fom brun et al (1984) "generic" HRM functions: for example;

- HRM policies: developing policies relating to personnel management of the firm;

- Employment: defining recruitment and selection procedures for staffing needs;

- Development: developing strategies for training and development of employees;

- Performance: developing performance appraisal programs;

- Compensation: Designing reward systems for the employees.

These HR functions are actually performed via different HRM practices in organizations. From above discussion, these generic HRM practices are explained below with the help of available literature for exploring the level of HRM sophistication in selected SMEs to investigate its association with firm performance.

\section{References}

Aldrich, H., \& Von Glinow, M. A. (1991). Business starts-ups: The HRM imperative. In Cardon, M. S. \& Stevens, C. E. (Eds.), Managing human resources in small organizations: What do we know? (pp. 295-323, Vol. 14, No. 3, 2004). Human Resource Management Review.

Bacon, N., Ackers, P., Storey, J., \& Coates, D. (1996). It's a Small World: Managing Human Resources in Small Businesses. The International Journal of Human Resource Management, 7(1), 82-100. http://dx.doi.org/10.1080/09585199600000119

Brand M.J., \& E.H. Bax. (2002, December). Strategic HRM for SMEs: implications for firms and policies. Education and Training Journal, 44(8), 451-463. http://dx.doi.org/10.1108/0040091020449295

Cardon, M. S., \& Stevens, C. E. (2004). Managing human resources in small organizations: What do we know? Human Resource Management Review, 14(3), 295-323. http://dx.doi.org/10.1016/j.hrmr.2004.06.001

Flanagan D.S., \& S.P. Despande. (1996). Top management's perceptions of changes in HRM practices after union elections in small firms. Journal of Small Business Management, 34(4), 23-34.

Fombrun, C, Tichy, N. M., \& Devanna, M . A. (1984). Strategic Human Resource Management. New York: Wiley.

Hendy, C., \& Pettigrew, A. (1992). Patterns of Strategic Change in the Development of Human Resource $\begin{array}{lllll}\text { Management. British Journal of } & \text { Management, } & 3(3), & \text { 137-156. }\end{array}$ http://dx.doi.org/10.1111/j.1467-8551.1992.tb00041.x 
Hornsby, J. S., \& Kuratko, D. E. (1990). Human Resource Management in small Business: Critical Issues for the 1990s. Journal of Small Business Management, 28(3), 918.

Huselid, M.A. (1995). The impact of human resource management practices on turnover, productivity, and corporate financial management. Academy of Management Journal, 38(3), 635-672. http://dx.doi.org/10.2307/256741

Jones, F. F., Morris, M. H., \& Rockmore, W. (1995). HR practices that promote entrepreneurship. HR Magazine, $40(5), 86$.

Marlow, S., \& D. Patton. (1993). Managing the employment relationship in the small firm: Possibilities for human resource management. International Small Business Journal, 11(4), 57-64. http://dx.doi.org/10.1177/026624269301100404

Mathis, R.L., \& I. H. Jackson. (1991), Personnel/Human Resource Management. West Publishing Company, St. Paul, Minn.

McEvoy, G.M. (1984). Small business personnel practices. Journal of Small Business Management, 22(4), 1-8.

Perry, J.L. (1993). Strategic human resource management. Review of Public Personnel Administration, 13(4), 50-71. http://dx.doi.org/10.1177/0734371X9301300405

Pfeffer, J. (1994). Competitive advantage through people: Unleashing the power of the workforce. Boston: Harvard Business School Press.

Prahalad, C.K. (1983). Developing strategic capability: An agenda for top management. Human Resource Management, 22(3), 237-254. http://dx.doi.org/10.1002/hrm.3930220304 